\title{
Observations of Two Non-native Snake Species in the Same Remote Area of Southern Florida
}

Emma B. Hanslowe, Bryan G. Falk, Michelle A. McEachern, and Robert N. Reed

U.S. Geological Survey, Fort Collins Science Center, 2150 Centre Avenue, Building C, Fort Collins, Colorado 80526 (reedr@usgs.gov)

Photographs by the senior author.

$\mathrm{E}_{\mathrm{s}}^{\mathrm{x}}$ xotic species can impact both the economy and ecosystems of an introduced range (Pimentel et al. 2005; Pimentel 2007). By 2010 in Florida, 137 species of nonnative amphibians and reptiles were known to have been introduced and 56 had become established (Krysko et al. 2011). Many reports of non-native snakes are associated with urban areas and are presumed to be the result of pets that are released or escape from human dwellings. However, nonnative snakes are occasionally found in natural areas, presenting a special concern for land managers. The Burmese Python (Python bivittatus), a well-known large constrictor established in southern Florida, appears to be causing acute declines in mammalian populations in the Greater Everglades ecosystem, and additional species of constrictors could impose even greater negative effects in Florida if they became established (Reed 2005; Snow et al. 2007; Kraus 2009; Reed and Rodda 2009; Dorcas et al. 2012; McCleery et al. 2015).

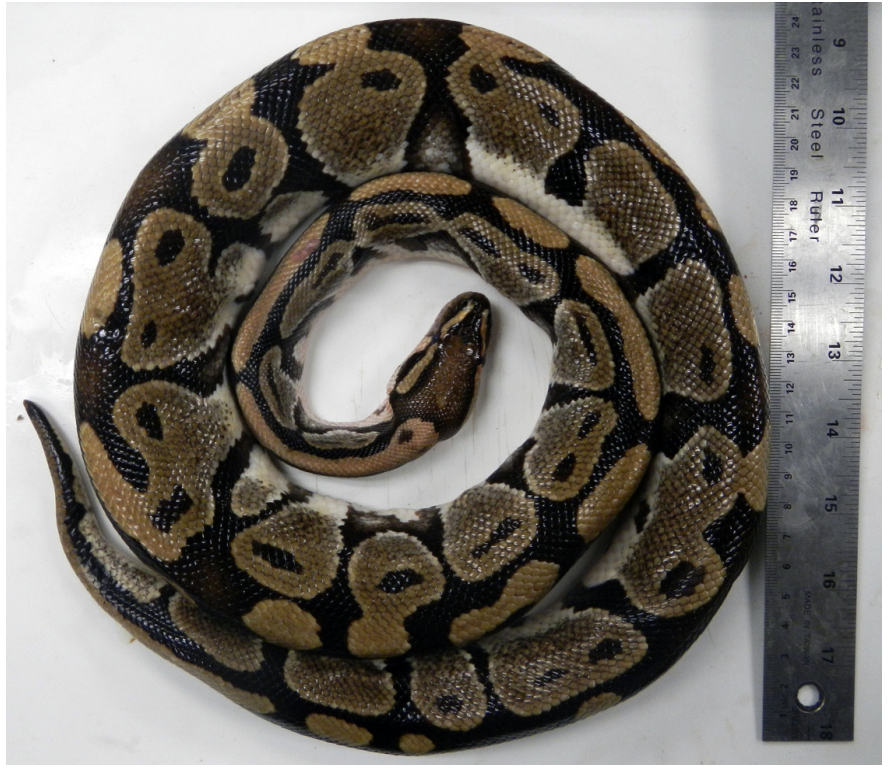

Fig. 1. Adult male Ball Python (Python regius) captured on 29 November 2014 in Big Cypress National Preserve, Florida.
Here we report two non-native snakes found approximately one month apart in the same remote locality in Big Cypress National Preserve (BCNP), Collier County, Florida.

A camper captured an adult male Ball Python (Python regius) on 29 November 2014 at $1530 \mathrm{~h}$ in Midway Campground within BCNP $\left(25^{\circ} 50^{\prime} 59.66^{\prime \prime} \mathrm{N}\right.$, $\left.80^{\circ} 59^{\prime 2} 24.11^{\prime \prime W}\right)$. The snake (113 cm SVL, $122 \mathrm{~cm}$ TL, 0.998 kg mass; Fig. 1) was discovered in grass adjacent to a paved road. The captured python was surrendered to a BCNP law enforcement ranger, who transferred it to the authors. The snake was alive but appeared lethargic and in extremely poor condition and was euthanized (Big Cypress National Preserve Accession \# BICY 00351; Catalogue \# BICY 14986).

Four weeks later, in the early afternoon of 25 December 2014, BCNP law enforcement officers captured an adult female Dumeril's Boa (Acrantophis dumerili) $101 \mathrm{~m}$ from where the Ball Python had been found (2550'56.54"N, $80^{\circ} 59^{\prime} 22.96$ 'W). Upon capture, the snake (208 cm SVL, $222 \mathrm{~cm}$ TL, $7.020 \mathrm{~kg}$ mass; Fig. 2) was coiled with its head

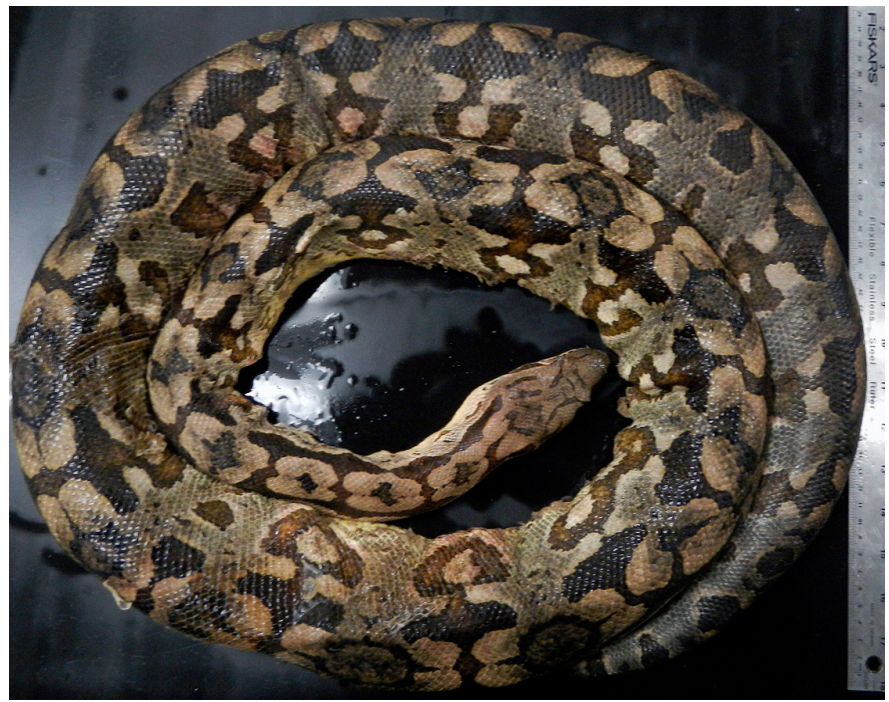

Fig 2. Adult female Dumeril's Boa (Acrantophis dumerili) captured on 25 December 2014 in Big Cypress National Preserve, Florida. 
beneath its body in grass adjacent to brushy vegetation. It was transferred to the authors, who euthanized it after observing its inflamed skin, a severe respiratory infection, and overall lethargy (Big Cypress National Preserve Accession \# BICY 00351; Catalogue \# 14976).

Neither $P$. regius nor $A$. dumerili occur naturally in Florida. In its native range in central and western Africa, $P$. regius inhabits dry grasslands, savannas, and forest edges (Bauchot 1994; Barker and Barker 2006), whereas A. dumerili is native to the forests of southern Madagascar (Bauchot 1994; Raxworthy 2003). The introduction pathway of both $P$. regius and $A$. dumerili to Florida is almost certainly the pet trade. Since 2009, 152 sightings of $P$. regius across 31 Florida counties have been reported, largely from urban and suburban areas (www.eddmaps.org; Fig. 3). Only four $A$. dumerili sightings have been reported to the Early Detection and Distribution Mapping System, all from densely populated areas of Miami-Dade County (www.eddmaps.org; Fig. $3)$. Thus far no evidence suggests that either species has successfully reproduced in Florida outside of captivity (Krysko et al. 2011). Midway Campground is at least thirty miles from the western edge of the Miami metropolitan area, which is the nearest major human population center. That both snakes were captured within one month of each other and at the same remote locality suggests a single pet-release event in which the owner(s) may have traveled a long distance to intentionally release these snakes in a natural area. We do not know whether the snakes were released in poor health or became unhealthy following release. We also were unable to determine whether additional individuals of these or different species were released at the same time.

\section{Acknowledgments}

Funding was provided by Everglades National Park, the Greater Everglades Priority Ecosystem Science Program, and the USGS Invasive Species Science Program. We thank F. Ridgley and the Zoo Miami Conservation and Research Department for assistance with euthanasia of both snakes, BCNP law enforcement officers S. Herrin, A. Mezera, and B. Standish for assistance with the capture and transfer of both snakes, and the reviewers for providing helpful comments on this paper. Any use of trade, product, or firm names is for descriptive purposes only and does not imply endorsement by the United States Government.

\section{Literature Cited}

Barker, D.G. and T.M. Barker. 2006. Pythons of the World, Volume II: Ball Pythons. The History, Natural History, Care, and Breeding. Vida Preciosa International, Inc., Library, Boerne, Texas.

Bauchot, R. 1994. Snakes: A Natural History. Sterling Publishing Company, Inc., New York, New York.

Dorcas, M.E., J.D. Willson, R.N. Reed, R.W. Snow, M.R. Rochford, M.A. Miller, W.E. Meshaka, P.T. Andreadis, F.J. Mazzotti, C.M. Romagosa, and K.M. Hart. 2012. Severe mammal declines coincide with proliferation of invasive Burmese Pythons in Everglades National Park. Proceedings of the National Academy of Sciences of the United States of America 109:2418-2422.

Early Detection and Distribution Mapping System. 2015. <www.eddmaps.org>.

Kraus, F. 2009. Alien Reptiles and Amphibians: A Scientific Compendium and Analysis. Springer, Dordrecht, The Netherlands.

Krysko, K.L., J.P. Burgess, M.R. Rochford, C.R. Gillette, D. Cueva, K.M. Enge, L.A. Somma, J.L. Stabile, D.C. Smith, J.A. Wasilewski, G.N. Kieckhefer III,

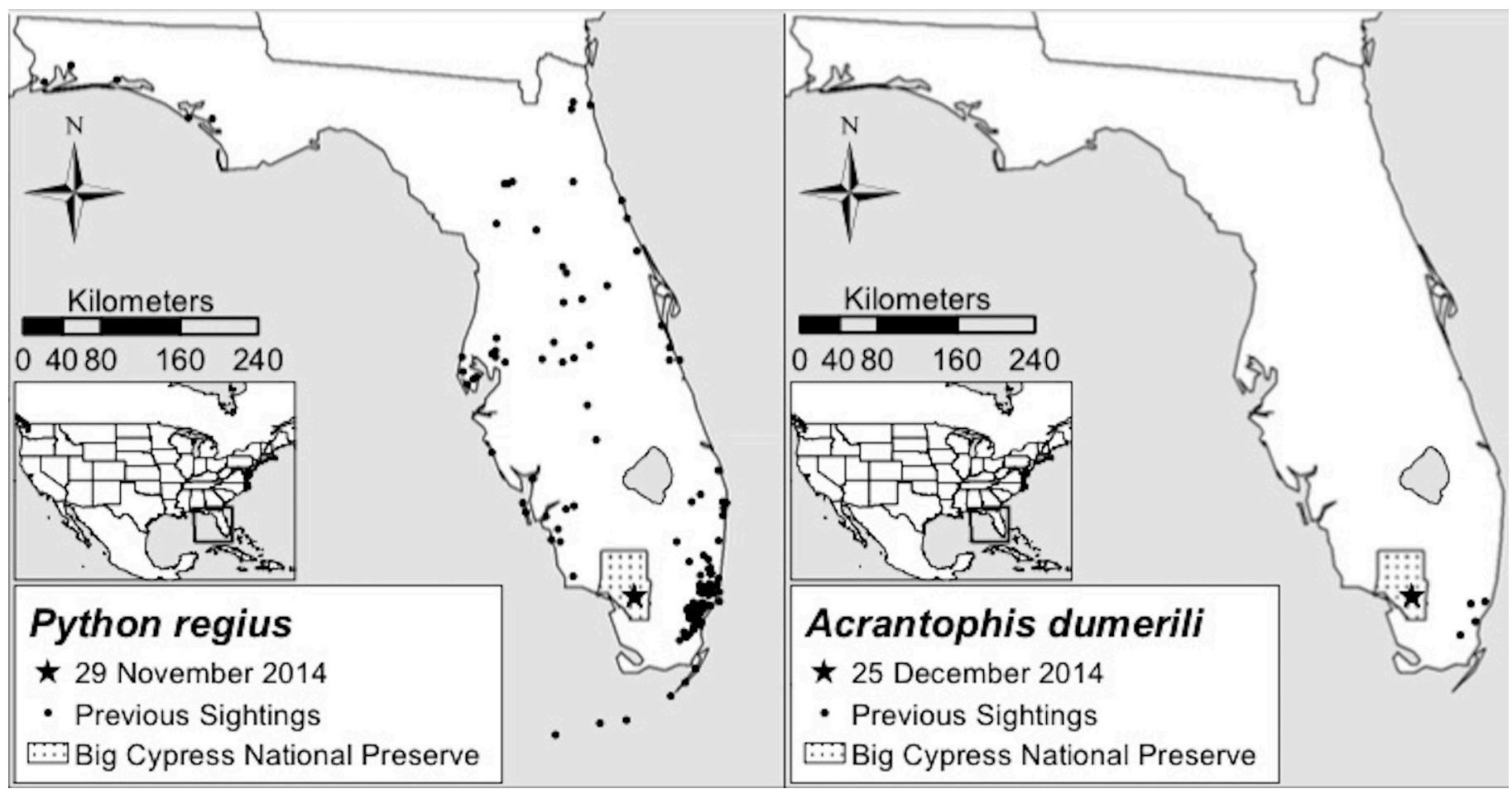

Fig 3. Maps of Ball Python (Python regius) (left) and Dumeril's Boa (Acrantophis dumerili) (right) sightings in Florida reported to the Early Detection and Distribution Mapping System in comparison to the snakes captured on 29 November 2014 and 25 December 2015 in Big Cypress National Preserve, Florida. 
M.C. Granatosky, and S.V. Nielsen. 2011. Verified non-indigenous amphibians and reptiles in Florida from 1863 through 2010: Outlining the invasion process and identifying invasion pathways and stages. Zootaxa 3028:1-64.

McCleery, R.A., A. Sovie, R.N. Reed, M.W. Cunningham, M.E. Hunter, and K.M. Hart. 2015. Marsh rabbit mortalities tie pythons to the precipitous decline of mammals in the Everglades. Proceedings of the Royal Society of London B: Biological Sciences 282:20150120.

Pimentel, D. 2007. Environmental and economic costs of vertebrate species invasions into the United States, pp. 2-8. In: G.W. Witmer, W.C. Pitt, and K.A. Fagerstone (eds.), Managing Vertebrate Invasive Species: Proceedings on an International Symposium. United States Department of Agriculture-Animal and Plant Health Inspection Service. Wildlife Services National Wildlife Research Center, Fort Collins, Colorado.

Pimentel, D., R. Zuniga, and D. Morrison. 2005. Update on the environmental and economic costs associated with alien-invasive species in the United States. Ecological Economics 52:273-288.
Raxworthy, C.J. 2003. Boas, Boidae, pp. 993-997. In: S.M. Goodman and J.P. Benstead (eds.), The Natural History of Madagascar. University of Chicago Press, Chicago, Illinois.

Reed, R.N. 2005. An ecological risk assessment of nonnative boas and pythons as potentially invasive species in the United States. Risk Analysis 25:753-766.

Reed, R.N. and G.H. Rodda. 2009. Giant constrictors: Biological and management profiles and an establishment risk assessment for nine large species of pythons, anacondas, and the boa constrictor. U.S. Geological Survey OpenFile Report 2009-1202. Wildlife Services National Wildlife Research Center, Fort Collins, Colorado.

Snow, R.W., K.L. Krysko, K.M. Enge, L. Oberhofer, A. Warren-Bradley, and L. Wilkins. 2007. Introduced populations of Boa constrictor (Boidae) and Python molurus bivittatus (Pythonidae) in southern Florida, pp. 416-438. In: R.W. Henderson and R. Powell (eds.), The Biology of Boas and Pythons. Eagle Mountain Publishing, Eagle Mountain, Utah. 